\title{
Tinjauan Kriminologi Terhadap Kejahatan Asusila Melalui Dunia Maya di Makassar
}

\author{
Herman \\ Manajemen Informatika, STMIK Handayani, Makassar, 90232 \\ Email: herman_ph@yahoo.co.id
}

\begin{abstract}
Abstrak - Penelitian ini bertujuan untuk menganalisis dan menjelaskan (1) faktor-faktor terjadinya kejahatan asusila melalui dunia maya di Makassar (2) cara pencegahan terjadinya kejahatan asusila melalui dunia maya di Makassar. Penelitian ini dilaksanakan di kota Makassar khusus di Polrestabes Makassar. Data yang diambil berupa data primer yang diperoleh langsung dari narasumber yang berkaitan dengan kejahatan asusila melaui dunia maya di Makassar sedangkan data sekunder adalah data yang diperoleh melalui data kepustakaan. Adapun Sampel dalam penelitian ini adalah 1 detektif, 1 Kanit, 3 penyidik Polres Makassar, 5 tokoh masyarakat, 5 tokoh agama, 5 tokoh pemuda dan 10 pelaku. kejahatan asusila melalui dunia maya. Hasil penelitian menunjukkan bahwa terjadinya kejahatan asusila melalui dunia maya di Makassar adalah disebabkan oleh beberapa faktor yaitu; kesadaran hukum, struktur hukum, budaya hukum dan lingkungan. Dari berbagai faktor yang telah penulis uraikan di atas tentunya kesadaran hukum yang menjadi prioritas untuk menanamkan nilai-nilai yang baik dalam diri setiap individu sehingga menyadari bahwa tindak kejahatan asusila adalah tindakan yang tidak bermoral serta melanggar peraturan perundang-undangan. Berdasarkan hasil penelitian, maka penulis dapat menyimpulkan bahwa diperlukan maksimalisasi dari aparat penegak hukum untuk melakukan sosialisasi dalam rangka peningkatan kesadaran hukum di dalam masyarakat serta menindak tegas para pelaku kejahatan asusila melalui dunia maya agar menjadi efek jerah bagi pelaku serta masyarakat umum. Penulis juga berharap kepada kepolisian Resor Kota Besar Makassar untuk melakukan pencegahan kejahatan asusila melalui dunia maya dengan melalukan tiga langkah pencegahan yakni; Pre-entif, Preventif dan Refresif.
\end{abstract}

Kata Kunci- Tinjauan Kriminologi,Kejahatan Asusila, Dunia Maya, Makassar

\section{PENDAHULUAN}

Negara Indonesia adalah Negara yang berdasarkan hukum sebagaimana tertuan dalam undangundang dasar Negara repoublik Indonesia 1945 (UUD NRI 1945). Asas ini tentunya bertujuan untuk mewujudkan kehidupan berbangsa dan bernegara yang aman, damai dan tentram, dimana Setiap warga negara memiliki kewajiban untuk menegakkan hak asasi manusia, dan negara memiliki kewajiban untuk memastikan bahwa semua warga negara sama di depan hukum.
Peran hukum sebagai alat kontrol sosial (social engineering) dan hukum sebagai alat integratif masyarakat berfungsi untuk melindungi kepentingan manusia. (Sajipto Raharjo, 1983: 127).

Perkembangan tegnologi dan informasi yang begitu cepat sangat mempengaruhi kehidupan berbangsa dan bernegara baik dari segi politik, ekonomi, social maupun hukum. Teknologi informasi juga membawa peradaban terhadap manusia menjadi masyarakat informasi. Masyarakat yang dulunya sangat susah untuk mendapatkan ataupun memberikan informasi namun dengan seiring berkembangnya zaman masyarakat begitu dimudahkan untuk mendapatkan informasi dengan hitungan detik.

Keunggulan komputer didorong oleh kemajuan teknologi informasi dan komunikasi terutama berupa kecepatan dan ketepatan dalam menyelesaikan pekerjaan, mengurangi tenaga kerja dan biaya, dan mengurangi kemungkinan kesalahan, membuat orang semakin tergantung. Komputer. Hal ini dibantu oleh media yang memungkinkan kinerja komputer itu sendiri, yaitu media internet.

Internet dulunya mewakili kepentingan kelompok tertentu yaitu militer, pemerintah dan akademisi, namun sekarang internet bisa digunakan oleh semua orang, mulai dari pebisnis hingga politisi dan kalangan lainnya, bahkan para kriminal. Politisi menggunakan Internet sebagai alat untuk memenangkan suara dan massa, pengusaha menggunakan Internet sebagai kendaraan untuk menjual transaksi bisnis, dan ada banyak manfaat yang dapat dicapai melalui Internet. Internet adalah ruang informasi dan komunikasi yang menjanjikan untuk melampaui batas antar negara dan mempercepat penyebaran dan pertukaran pengetahuan dan ilmuwan di seluruh dunia. Internet juga telah membawa kita ke sebuah ruang atau "dunia baru" yang diciptakan sebagai dunia maya. (Agus Raharjo, 2002: 4).

Perkembangan teknologi selalu memberikan dampak langsung atau tidak langsung, positif atau negatif, dan akan sangat mempengaruhi setiap sikap dan pola pikir setiap anggota masyarakat (Andi Hamzah, 1992:10). Tidak dapat dipungkiri bahwa teknologi komunikasi memiliki dampak negatif yang tidak kalah dengan manfaat yang dicapai. Dampak negatif dapat terjadi ketika terjadi kesalahan komputer, yang mengakibatkan kerugian besar bagi pengguna atau calon pelanggan. Bug dengan sengaja menyebabkan penyalahgunaan komputer (Andi Hamzah, 1992:24).

Penyalahgunaan teknologi informasi, khususnya komputer, akhir-akhir ini menjadi masalah bagi sebagian 
pengguna komputer, karena penyalahgunaan komputer telah menyebabkan kejahatan yang ditujukan tidak hanya terhadap komputer pada umumnya, tetapi juga terhadap sistem dan jaringan komputer serta para pengguna komputer di seluruh jagat raya. Kejahatan di dunia maya biasa disebut dengan cybercrime. Cybercrime adalah tindakan kriminal yang dilakukan oleh individu atau sekelompok individu atau organisasi dengan menggunakan atau membidik komputer, sistem komputer, atau jaringan komputer. Kejahatan ini terjadi di dunia maya (virtual) sehingga memiliki karakteristik yang berbeda dengan kejahatan tradisional (Widodo, 2009: 3). Cybercrime adalah sisi gelap dari kemajuan teknologi yang berdampak sangat luas pada seluruh kehidupan modern saat ini (Barda Nawai Arif, 2006: 2). Evolusi cybercrime juga tercermin dari munculnya berbagai istilah seperti white collar cybercrime, EFT (Electronic Funds Transfer) crime, cybank crime, internet banking crime, online business crime, cyber/electronic money laundering, Hitech WWC (economic crime). ), cyber fraud, cyber terrorism, cyber stalking, cyber sex, cyber pornografi anak, cyber fitnah, penjahat cyber dan lain-lain (Barda Nawai Arif, 2006:127). Kejahatan asusila di dunia maya sering disebut dengan cyber porn, yang meliputi cyber sex dan cyber pornografi anak.

Perkembangan ilmu komunikasi dan elektronika berdampak besar terhadap munculnya kejahatan asusila di dunia maya. Belakangan ini banyak ditemukan atau beredar video cabul yang sengaja direkam kemudian secara tidak sengaja, sengaja atau lalai disebarluaskan kepada masyarakat, disebabkan oleh mudahnya akses internet melalui komputer, handphone dan media komunikasi lainnya serta penyebaran konten cabul menjadi video yang didistribusikan melalui Internet. sengaja atau tidak sengaja disebarluaskan di masyarakat. Tidak hanya tentang penyebaran video cabul yang sekarang kita jumpai di dunia maya, tetapi juga termasuk tindakan tidak pantas lainnya yang terkait dengan kejahatan asusila, sehingga tindakan tersebut membingungkan sebagian orang ketika mereka memahami dan memahami apakah tindakan tersebut dapat didefinisikan sebagai tindakan. tidak bermoral atau tidak. Cyberspur merupakan masalah serius di Indonesia mengingat banyaknya situs web melalui Internet yang dapat diakses 24/7 tanpa gangguan. Berdasarkan latar belakang pemikiran di atas, penulis melanjutkan judul:"Tinjauan Kriminologi Terhadap Kejahatan Asusila Melalui Dunia Maya Di Makassar"

\section{METODOLOGI}

\subsection{Metode penelitian hukum empiris}

Metode penelitian ini merupakan penelitian hukum yang menarik perhatian pada masalah hukum yang berkaitan dengan kesenjangan antara yang boleh dan yang tidak boleh dilakukan (yang seharusnya). (Syaharuddin Nawi, 2014: 17).

Metode penelitian hukum empiris juga berfungsi untuk melihat hukum dalam arti yang sebenarnya dan untuk mengkaji bagaimana hukum itu bekerja dalam masyarakat. Karena penelitian ini mengkaji manusia dalam konteks kehidupannya di masyarakat, maka metode penelitian hukum empiris dapat disebut sebagai penelitian hukum sosiologis. Dapat dikatakan bahwa penelitian hukum diambil dari fakta-fakta yang ada dalam suatu masyarakat, badan hukum atau instansi pemerintah.

2.2 Lokasi Penelitian Penulis memilih lokasi penelitian di Kota Makassar yang termasuk dalam wilayah hukum Polres Makassar. Alasan pemilihan lokasi penelitian ini terutama karena semakin banyaknya tindak pidana yang diproses oleh kepolisian kejahatan asusila melalui dunia maya.

2.3 Populasi dan Sampel Populasi penelitian ini terdiri dari semua perangkat kepolisian Makassar yang bergerak dalam upaya pencegahan kejahatan asusila melalui dunia maya dan individu yang diyakini memiliki pengetahuan tentang penyebab kejahatan asusila melalui dunia maya dan kejahatan asusila melalui pengetahuan tentang dunia maya. Sedangkan sampel dalam penelitian ini adalah 1 Kapolsek, 1 penyidik Kanit dan 3 Polrestabes Makassar, 5 tokoh masyarakat, 5 tokoh agama, 5 tokoh pemuda dan 10 pelaku kejahatan asusila di dunia maya.

Pertimbangan peneliti memilih 5 tokoh masyarakat, 5 tokoh agama, 5 tokoh pemuda, dan 10 remaja yang melakukan tindak pidana asusila di dunia maya karena sampelnya cukup representatif untuk memberikan informasi tentang faktor-faktor apa saja yang menjadi penyebab terjadinya tindak pidana asusila di dunia maya di kota tersebut. Makassar. Sedangkan pertimbangan peneliti untuk memilih 1 Kepala Bareskrim, 1 Kanit dan 3 Penyidik dari Polrestabes Makassar karena peneliti berharap dan yakin akan memperoleh informasi tentang upaya kepolisian membatasi terjadinya kejahatan asusila melalui dunia maya di Kota Makassar mengatasi.

Teknik pemilihan sampel dalam penelitian ini dilakukan melalui target sampling yaitu dengan menunjuk peneliti secara langsung untuk dijadikan sampel penelitian.

\subsection{Sumber Data}

Sumber data yang akan digunakan dalam penelitian ini terdiri atas dua kategori, yaitu data primer dan data sekunder.

1. Data primer adalah data yang diperoleh langsung dari narasumber di lokasi penelitian mengenai kejahatan asusila tentang dunia maya di Kota Makassar.

2. Data sekunder adalah data yang diperoleh melalui studi kepustakaan, yaitu tinjauan pustaka, artikel, pemberitaan, makalah dan 
peraturan perundang-undangan yang terkait dengan tinjauan kriminologi tindak pidana asusila melalui dunia maya.

2.5 Teknik Pengumpulan Data

Metode pengumpulan data dilakukan dengan dua cara yaitu :

1. Penelitian kepustakaan (library research) Artinya, penulis mengumpulkan data dengan membaca seperangkat literatur yang relevan dengan tinjauan kriminologi kejahatan asusila melalui dunia maya, serta bahan normatif berupa produk hukum yaitu Kitab Undang-Undang Hukum Acara Pidana (KUHAP), UU No. tahun 2008 tentang informasi dan transaksi elektronik.

2. Penelitian di Lapangan (Field Research)

a). Observasi (Observation)

Artinya, penulis mengunjungi lokasi penelitian, kemudian secara langsung dan cermat mengamati subjek penelitian untuk mengetahui faktor-faktor yang mempengaruhi terjadinya kejahatan asusila melalui dunia maya dan upaya polisi dalam memerangi kejahatan asusila melalui dunia maya di Kota Makassar..

b). Wawancara (Interview)

Yaitu, penulis melakukan tanya jawab (wawancara) dengan sejumlah individu yang berpengetahuan seperti remaja yang melakukan kejahatan asusila di dunia maya dan penyidik dari Polres Makassar, serta tokoh masyarakat, agama dan pemuda dalam upaya untuk melakukan ini memerangi terjadinya kejahatan asusila melalui dunia maya di kota. Makassar.

c). Dokumentasi (Documentation)

Artinya, penulis mengumpulkan data tentang kejahatan asusila di dunia maya dan tentang upaya polisi dalam memerangi kejahatan tidak senonoh di dunia maya di kota di lokasi penelitian. Makassar

\subsection{Teknik Analisis Data}

Data penelitian diolah dan dianalisis secara kualitatif, yaitu analisis data menurut kualitasnya kemudian dideskripsikan dengan kata-kata sehingga timbul pembahasan atau penjelasan dalam bentuk kalimat yang sistematis dan dapat dipahami, kemudian ditarik kesimpulan.

\section{HASIL DAN PEMBAHASAN}

Akhir akhir ini sering kita temukan gambar-gambar ataupun tulisan yang melanggar kesusilaan di dunia maya. Hal ini cukup memprihatinkan karena dampak dari kejahatan itu dirasakan oleh seluruh lapisan masyarakat mulai orang tua sampai pada anak-anak. Hal ini terjadi karena pengguna media sosial hampir semua kalangan menggunakan dan bahkan anak-anak dibawah umur sekalipun.
Meskipun Undang-undang No. 11 tahun 2008 tentang Informasi dan Transaksi Elektronik telah diundangkan bebarapa tahun yang lalu namun kejahatan asusila didunia maya semakin meningkat dan bahkan tidak ada jalan keluar. Sering kali kita saksikan kejahatan asusila didunia maya namun yang berujung pada proses hukum sangat minim, hal ini disebabkan karena yang menjadi korban kejahatan ini lebih memilih jalan damai daripada menempuh proses hukum yang berlarut-larut.

Salah satu alasan sehingga kasus kejahatan asusila melalui dunia maya ini tidak sampai pada proses hukum, karena korban maupun keluarga korban tidak ingin masalahnya di ketahui banyak orang karena itu masalah pribadi dan menjadi aib bagi korban ataupun keluarga korban. Menurut Kasatreskrim polrestabes Makassar mengatakan bahwa; kasus asusila melalui dunia maya hampir tidak ada yang sampai ke kepolisian kalaupun ada yang sampai itu biasanya berujung damai"

Adapun hasil wawancara yang penulis peroleh dari pelaku Tindak kejahatan asusila melalui dunia maya dapat dilihat dalam Tabel dibawah ini:

Tabel 1. Hasil wawancara

\begin{tabular}{|l|c|c|l|l|}
\hline No. & Nama & $\begin{array}{c}\text { Usia } \\
\text { Pelaku }\end{array}$ & $\begin{array}{c}\text { Pengetahuan } \\
\text { Tentang UU } \\
\text { ITE }\end{array}$ & $\begin{array}{c}\text { Modus } \\
\text { Tperandi }\end{array}$ \\
\hline 1 & ZF & 31 Tahun & Idak Tahu & $\begin{array}{c}\text { Mengirim } \\
\text { Gambar }\end{array}$ \\
\hline 2 & AR & 15 Tahun & Tidak Tau & $\begin{array}{c}\text { Mengirim } \\
\text { Gambar }\end{array}$ \\
\hline 3 & RY & 26 Tahun & Tidak Tahu & $\begin{array}{c}\text { Mengirim } \\
\text { Tulisan }\end{array}$ \\
\hline 4 & AD & 19 Tahun & Tidak Tahu & $\begin{array}{c}\text { Mengirim } \\
\text { Gambar }\end{array}$ \\
\hline 5 & Rs & 22 Tahun & Tahu & $\begin{array}{c}\text { Mengirim } \\
\text { Gambar }\end{array}$ \\
\hline 7 & Fd & 35 Tahun & Tidak Tahu & $\begin{array}{c}\text { Mengirim } \\
\text { Gambar }\end{array}$ \\
\hline 8 & Tm & 21 Tahun & Tidak Tahu & $\begin{array}{c}\text { Mengirim } \\
\text { Tulisan }\end{array}$ \\
\hline 9 & Fr & 27 Tahun & Tahu & $\begin{array}{c}\text { Mengirim } \\
\text { Gambar }\end{array}$ \\
\hline 10 & Js & 23 Tahun & Tidak Tahu & $\begin{array}{c}\text { Mengirim } \\
\text { Gambar }\end{array}$ \\
\hline
\end{tabular}

Berdasarkan Tabel diatas kemudian penulis klasifikasikan dalam bentuk diagram batang sebagai berikut;

\section{Data Usia Pelaku Tindak Asusila Melalui Dunia Maya}

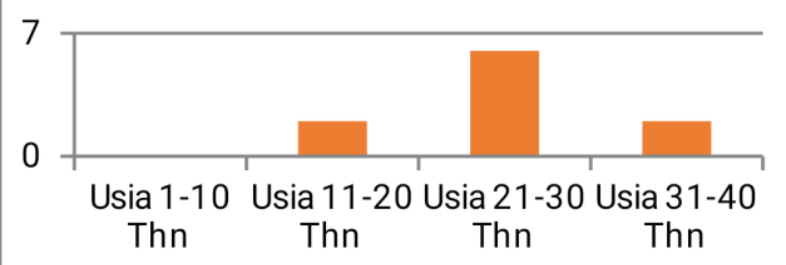


Gambar 1. Diagram batang data usia pelaku tindak asusila

Berdasarkan diagram batang diatas dapat disimpulkan baha usia pelaku kejahatan asusila melalui dunia maya itu paling banyak atau sekitar $60 \%$ dilakukan oleh usia 21 sampai 30 tahun. Hal ini disebabkan karena diusia tersebut seseorang tidak lagi dalam pengawasan orang tua sehingga kesempatan untuk melakukan tindak kejahatan asusila melalui dunia maya itu sangat besar. Sedangkan $20 \%$ dilakukan oleh seseorang yang berusia sekitar 11-20 tahun, hal ini disebabkan karena diusia itu masih dalam pengawasan orang tua sehingga kesempatan untuk melakukan kejahata asusila didunia maya sangat kurang. Dan 20\% dilakukan oleh usia 30-40 tahun yang menurut penulis itu disebabkan karena pengguna media sosial diusia itu sangat kurang.

\section{Data Cara Laksana Tindak Kejahatan ...}

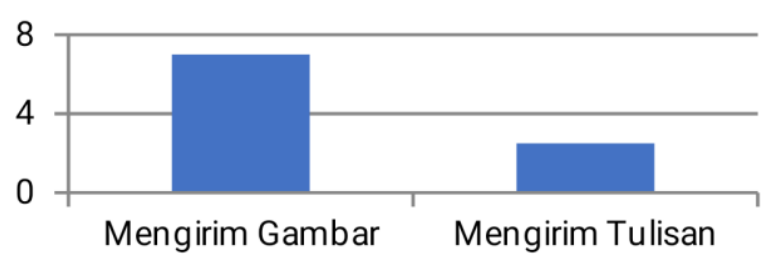

Gambar 1. Diagram batang data cara laksana tindak kejahatan

Berdasarkan diagram batang diatas dapat kita lihat bahwa modus operandi tindak kejahatan asusila melalui dunia maya itu $80 \%$ dilakukan dengan cara mengirim gambar dimedia social dan $20 \%$ dilakukan dengan cara mengirim tulisan dimedia social. Kebanyakan dari gambar yang dikirim adalah tidak mengarah pada orang tertentu ataupun ingin melecehkan seseorang namun gambar-gambar yang dikirim adalah gambar orang yang melanggar kesusilaan dan tidak dikenali identitasnya dan berdasarka hasil wawancara dengan pelaku dapat penulis simpulkan bahwa kebanyakan mereka melakukan kejahatan asusila melalui dunia maya dengan sengaja dan hanya bersifat bahan candaan.

\section{Data Berdasarkan Tingkat Pengetahua...}

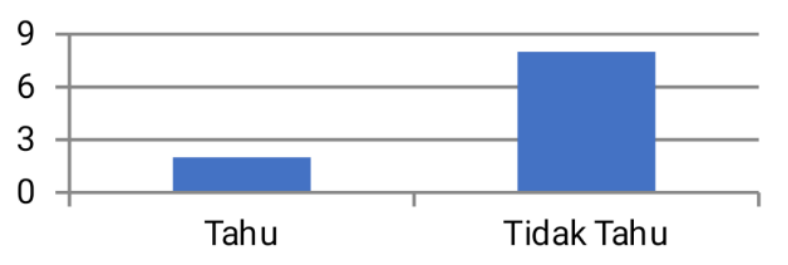

Gambar 1. Diagram batang data berdasarkan tingkat pengetahuan
Berdasarkan diagram batang diatas dapat penulis simpulkan bahwa tingkat pengetahuan pelaku tentang Undang-undang No. 11 Tahun 2008 Tentang Informasi dan Transaksi Elektronik itu $80 \%$ pelaku yang tidak tahu dan $20 \%$ pelaku yang tahu. Dari uraian diatas dapat kita lihat bahwa banyaknya pelaku yang tidak tahu bahwa ada aturan yang mengatur terkait dunia maya. Tentunya aparat penegak hukum harus lebih maksimal untuk melakukan sosialisasi dan penyuluhan hukum terkait undang-undang tersebut.

4.1 Faktor-faktor Terjadinya Kejahatan Asusila Melalui Dunia Maya di Makassar

Adanya perkembangan teknologi tentunya membawa pengaruh bagi kehidupan. Pengaruh tersebut meliputi dua sisi yaitu pengaruh positif dan pengaruh negatif. Dampak-dampak pengaruh globalisasi tersebut kita kembalikan kepada diri kita sendiri sebagai generasi muda agar tetap menjaga etika dan budaya, agar kita tidak terkena dampak negatif dari globalisasi. Namun Informasi yang tidak tersaring membuat tidak kreatif, prilaku konsumtif dan membuat sikap menutup diri serta berpikir sempit. Hal tersebut menimbulkan meniru perilaku yang buruk. Mudah terpengaruh oleh hal yang tidak sesuai dengan kebiasaan atau kebudayaan suatu negara yang tidak sesuai dengan norma-norma yang ada.

Kejahatan asusila lewat dunia maya juga membawa dampak buruk bagi bangsa Indonesia, kejahatan ini dapat merusak moral generasi bangsa hal ini sangat jelas bahwa yang menjadi korban adalah seluruh lapisan masyarakat mulai dari orang tua sampai pada anak dibawah umur itu terlihat karena penggunaan tegnologi itu adalah semua lapisan masyarakat.

Adapun fator-faktor terjadinya kejahatan asusila melalui dunia maya adalah sebagai berikut:

1. Kesadaran Hukum

Apa yang dilakukan Masyarakat akan berdampak besar pada profil penegakan hukum. Jika seorang anggota masyarakat terlibat dalam kegiatan ilegal, perilaku masyarakat itu sama saja dengan menantang aparat penegak hukum untuk menegakkan hukum..(Abdul Wahid :136).

Fungsi hukum pidana di bidang teknologi informasi secara umum adalah mengatur kehidupan manusia dalam hubungannya dengan kegiatannya di dunia maya guna mewujudkan masyarakat yang tertib dan damai. Sementara fitur spesifiknya adalah sebagai berikut:

a. Terpeliharanya kepentingan hukum seluruh anggota masyarakat, baik individu, kepentingan hukum masyarakat, maupun kepentingan hukum negara (misalnya keamanan negara) ketika menggunakan teknologi informasi untuk mencapai kemakmuran.

b. Perlindungan kepentingan hukum semua orang (perorangan dan badan hukum) yang diduga atau terbukti melakukan tindak pidana di bidang teknologi informasi;.

c. Perlindungan korban kejahatan di bidang teknologi informasi (Widodo, 2013 :18). 
Selama ini kesadaran hukum masyarakat Indonesia untuk fungsi ini dan untuk bereaksi terhadap kegiatan kejahatan dunia maya dirasa masih kurang. Hal ini antara lain disebabkan oleh kurangnya pemahaman dan pengetahuan masyarakat tentang jenis-jenis cybercrime. Minimnya pengetahuan tersebut membuat upaya penanggulangan cybercrime menghadapi kendala, dalam hal ini terkait dengan kesepakatan hukum dan proses kontrol masyarakat atas kegiatan yang diduga terkait dengan kejahatan Mayantara.Dengan pemahaman yang mendalam tentang cybercrime, peran masyarakat dalam upaya pengawasan menjadi sangat penting. Namun jika Jika masyarakat memiliki pengetahuan yang minim, peran mereka akan mandul. Dalam masyarakat yang kurang pengetahuan tentang kejahatan dunia maya, misalnya, seorang siswa datang dengan membawa banyak komputer dan di tempat baru ini, siswa memesan barangbarang mewah melalui carding. Karena orang tidak tahu dan tidak mengerti

Pakar Hukum UGM Yogyakarta, RM. Sudikno Mertokusumo (Pasal, 2008: 2) mengatakan bahwa kesadaran hukum mengacu pada kategori kehidupan intelektual individu, tetapi pada saat yang sama juga pada pandangan umum dalam masyarakat tertentu tentang apa hukum itu, apa yang harus kita lakukan. atau apa yang harus dilakukan untuk menegakkan hukum atau apa yang harus dilakukan. kita tidak boleh melakukan ini untuk menghindari pelanggaran hukum.

Bahkan Paul Scholten sendiri yang mencetuskan teori kesadaran hukumnya yang disebut Rechtsgefuhl atau Rechtsbewustzijn, secara tegas menyatakan bahwa kesadaran hukum merupakan landasan hukum bagi hukum positif (hukum tertulis), karena tidak ada hukum yang mengikat warga negara kecuali atas dasar kesadaran hukum. maka kebenaran adalah sumber dari segala hukum.

\section{Struktur Hukum}

Faktor penegakan hukum seringkali menjadi akar dari meningkatnya kejahatan dunia maya. Pada umumnya penyidik masih sangat sedikit menguasai pengoperasian komputer dan pemahaman komputer serta kemampuan untuk melakukan penyidikan dalam kasus-kasus tersebut. Beberapa faktor yang sangat berpengaruh (determinan) adalah:

a. Kurangnya pengetahuan tentang komputer

b. Pengetahuan teknis dan pengalaman para penyidik dalam menangani kasus-kasus cybercrime masih terbatas

c. Faktor sistem pembuktian yang menyulitkan para penyidik.

Selain itu, penting juga untuk diketahui bahwa dalam melakukan penyidikan kejahatan dunia maya, polisi dan penyidik harus saling berkoordinasi dan dapat meminta bantuan ahli yang diperlukan untuk melakukan penyidikan. Bahkan polisi dan penyidik resmi dapat meminta bantuan atas permintaan penyidik. negara lain untuk bertukar informasi dan bukti.

Menurut Lawrence Meir Friedman, struktur hukum disebut sistem struktural yang menentukan dapat atau tidaknya hukum dilaksanakan dengan baik. Bentuk hukum menurut Undang-Undang Nomor 8 Tahun 1981 meliputi: dimulai dari kepolisian, kejaksaan, pengadilan dan lembaga pemasyarakatan (lapas). Penegakan hukum dijamin oleh hukum. Jadi terlepas dari pengaruh kekuasaan negara dan pengaruh lainnya dalam pelaksanaan tugas dan tanggung jawabnya. Ada pepatah yang mengatakan: fiat justitia et pereat mundus - bahkan jika dunia berakhir, hukum harus dipatuhi. Hukum tidak dapat dilaksanakan atau ditegakkan tanpa adanya aparat penegak hukum yang kredibel, kompeten, dan independen. Akan lebih baik jika suatu peraturan hukum tidak didukung oleh aparat penegak hukum yang baik, keadilan hanya sebatas angan-angan.

Lemahnya mentalitas aparat penegak hukum menyebabkan penegakan hukum tidak berfungsi dengan baik. Banyak faktor yang menyebabkan lemahnya mentalitas aparat penegak hukum, antara lain pemahaman agama, ekonomi, kurangnya transparansi dalam proses perekrutan, dan sebagainya. Hal ini dapat digunakan untuk menekankan bahwa faktor penegakan hukum memainkan peran penting dalam berfungsinya hukum. Jika regulasinya bagus tapi kualitas penegakan hukumnya rendah, maka akan ada masalah. Sekalipun regulasinya buruk sementara kualitas penegakan hukumnya bagus, masih ada kemungkinan masalah akan muncul.

\section{Budaya Hukum}

Budaya hukum dapat didefinisikan sebagai sikap manusia tentang hukum dan sistem hukum, keyakinan, nilai dan harapan (Lawrence M Friedman: 1969). Seperti dikutip Hein Wangania, Friedman juga membedakan budaya hukum menjadi budaya hukum internal dan eksternal. Budaya hukum internal adalah budaya hukum warga negara yang melakukan tugas hukum tertentu, seperti: B. Polisi, jaksa dan hakim. Sedangkan budaya hukum eksternal adalah budaya hukum masyarakat pada umumnya (Tb. Ronny Rachman Nitibaskara, 2009).

Blankenburg berpendapat bahwa budaya hukum juga merupakan kumpulan sikap, keyakinan dan nilai hukum. Budaya hukum sendiri merupakan subkultur yang mengacu pada penghayatan dan sikap tindakan manusia terhadap hukum sebagai realitas sosial (Tb. Ronny Rachman Nitibaskara, 2009).

Kebudayaan bukan sekedar kumpulan dari bentuk-bentuk perilaku dan pemikiran yang saling lepas, tetapi kebudayaan didefinisikan sebagai suatu kategori residual, yang meliputi semua nilai-nilai kemasyarakatan yang berkaitan dengan hukum dan sikap yang mempengaruhi berjalannya hukum. termasuk menghormati atau mengabaikan hukum. kesediaan orang untuk memilih cara-cara informal untuk menyelesaikan perselisihan. Budaya hukum juga mencakup sikap dan tuntutan hukum yang diungkapkan oleh berbagai suku, ras, agama, kesempatan kerja dan kelas sosial (Hartoyo, 2007).

Budaya hukum merupakan respon berupa menerima atau menolak suatu peristiwa hukum, yang menunjukkan sikap perilaku manusia terhadap masalah hukum dan peristiwa hukum yang dibawa ke dalam masyarakat. 
Padahal, salah satu penyebab utama terjadinya kejahatan (cybercrime) ini adalah sikap kultural para pelaku hukum di negara kita. Di satu sisi, kita selalu melihat hukum sebagai bagian dari nilai-nilai ideal masyarakat kita. Sikap ini tentu saja bukan sikap yang tidak terpuji, tanpa sadar kita meletakkan hukum di menara gading. Jauh dari realitas kehidupan masyarakat sehari-hari. Sedangkan hukum adalah fenomena sosial, ia harus realistis, membumi dan memecahkan masalah sosial yang dihadapinya (Setiawan, 1998).

Salah satu faktor yang melatarbelakangi terjadinya kejahatan asusila melalui dunia maya adalah faktor budaya hukum. Menurut Lawrence Meir Friedman, budaya hukum adalah sikap manusia terhadap hukum dan sistem hukum - kepercayaan, nilai, pikiran, dan harapan. Budaya hukum adalah suasana pemikiran sosial dan kekuatan sosial yang menentukan bagaimana hukum diterapkan, dihindari, atau disalahgunakan. Budaya hukum erat kaitannya dengan kesadaran hukum masyarakat. Semakin tinggi kesadaran hukum masyarakat maka akan semakin tercipta budaya hukum yang baik dan dapat mengubah cara pandang masyarakat terhadap hukum sebelumnya. Sederhananya, tingkat kepatuhan masyarakat merupakan indikator berfungsinya hukum.

Analisis penulis terkait faktor budaya hukum yang menjadi salah satu factor terjadinya kejahatan asusila melalui dunia maya itu didukung oleh teori Asosiasi Diferensial yang menjelaskan bahwa adanya penyimpangan yang terjadi didalam masyarakat maka cenderung akan terjadi tindak kejahatan. Terjadinya penyimpangan tersebut akan menimbulkan kesadaran hukum dalam masyarakat sangat kurang sehingga kecenderungan untuk melakukan kejahatan sangat besar.

\section{Lingkungan}

Kejahatan tidak bermoral adalah tindakan manusia terhadap orang lain dalam masyarakat. Karena masyarakat adalah anggota masyarakat, maka kejahatan asusila tidak dapat dipisahkan dari masyarakat setempat. Lingkungan sosial tempat seseorang tinggal mempunyai pengaruh besar terhadap pembentukan perilaku kriminal, karena pengaruh sosialisasi seseorang tidak lepas dari pengaruh lingkungan..

Kota Makassar merupakan kota besar yang padat dengan penduduk dan penduduknya dipenuhi orang-orang dari berbagai daerah serta latar pendidikan yang berbeda pula. Sebagai kota besar tentunya tidak terlepas dari pengaruh teknologi informasi baik bersifat baik maupun buruknya. Kejahatan asusila lewat dunia maya sangatlah dipengaruhi oleh kondisi lingkungan yang padat dengan penduduk serta sikap apatis dan sifat individualis sehingga salin control satu sama lain dalam lingkungan masyarakat itu sangat minim.

Adapun analisis penulis terhadap faktor terjadinya kejahatan asusila lewat dunia maya bahwa asumsi dasar; Individu dalam masyarakat memiliki kecenderungan yang sama untuk menjadi baik atau buruk. Baik atau buruknya seseorang tergantung sepenuhnya pada lingkungan sosialnya. Jadilah baik ketika orang melakukannya dengan cara itu, dan menjadi buruk ketika masyarakat melakukannya dengan cara itu (John Hagan, 1987: 31).

4.2 Upaya Pencegahan dan Penanggulangan Kejahatan Asusila Melalui Dunia Maya di Kota Makassar

Tabel 2. Upaya pencegahan dan penaggulangan kejahatan asusila

\begin{tabular}{|c|c|c|}
\hline No. & Tahun & $\begin{array}{c}\text { Kejahatan Asusila Melalui } \\
\text { Dunia Maya di Kota } \\
\text { Makassar }\end{array}$ \\
\hline 1 & 2012 & - \\
\hline 2 & 2013 & - \\
\hline 3 & 2014 & - \\
\hline 4 & 2015 & 1 \\
\hline \multicolumn{2}{|c|}{$\begin{array}{c}\text { Jumlah Kasus Selama 4 } \\
\text { Tahun }\end{array}$} \\
\hline
\end{tabular}

Sumber: Polrestabes Makassar 2015

Berdasarkan table diatas terliahat bahwa dari tahun 2012 sampai pada tahun 2015 hanya satu kasus kejahatan asusila melalui dunia maya di Makassar yang dilaporkan pada kepolisian resor kota besar Makassar. Menurut Ibtu Ginanra Putri Kasubnit I Kepolisian resor kota besar Makassar bahwa; Banyak kasusu asusila melalui dunia maya di kota Makassar namun sangat minim atau hampir tidak ada orang ataupun yang menjadi korban yang melaporkan pada polisi, itu disebabkan karena rendahnya pengetahuan masyarakat terhadap undang-undang yang mengatur tentang kejahatan asusila melalui dunia maya UU nomor 11 tahun 2008 tentang Interaksi dan Transanksi Elektronik.

Adapun upaya yang harus dilakukan untuk mencegah kejahatan asusila melalui dunia maya di Makassar adalah sebagai berikut;

1. Pre-entif

Upaya pencegahan ini merupakan upaya pencegahan dini yang dilakukan untuk mencari akar permasalahan melalui upaya pendidikan dengan tujuan mempengaruhi masyarakat agar tidak berniat melakukan tindak pidana. asusila lewat dinia maya.

Pre-Emtif yang dilakukan untuk menanggulangi kejahatan asusila lewat dunia maya ini merupakan peran semua pihak baik kepolisian sebagai aparat penegak hukum maupun masyarakat. Menurut Fadli salah seorang tokoh pemuda yang penulis wawancarai mengatakan bahwa;

Untuk meminimalisir keajahatn asusila lewat dunia maya itu diperlukan peranan kepolisian untuk melakukan sosialisasi terkait aturan tindak kejahatan asusila, karena kita sebagai masyarakat hanya dapat memberikan teguran dan kalaupun ada yang jadi korban biasanya berakhir dengan jalan damai.

Berdasarkan pendapat diatas, penulis dapat berasumsi bahwa diperlukan maksimalisasi dari pihak kepolisian untuk melakukan pencegahan dini agar dapat meminimalisir tindak kejahatan asusila lewat dunia maya. 2. Preventif

Upaya preventif adalah upaya menghilangkan kesempatan untuk melakukan kejahatan. Upaya ini merupakan hasil dari upaya preventif yang kurang 
optimal dan menimbulkan niat untuk melakukan kejahatan.

Polisi Indonesia telah menggunakan berbagai cara. Menurut Kapolri Jenderal (Pol) Sutarman, polisi terus melakukan pengawasan perkembangan kejahatan asusila lewat dunia maya di Indonesia. Iya menyebutkan ratusan akun facebook yang terdeteksi namun sangat kesulitan untuk menindaki disebabkan banyaknya akun palsu ataupun identitas pelaku yang tidak jelas.

Berdasarkan hasil wawancara dengan pelaku, dalam tindak kejahatan asusila sangat mudah untuk dilakukan, karena mereka biasanya melakukan dirumah ataupun di warnet, selain itu pelaku juga melakukan tanpa ada ketakutan bahwa tindakan yang mereka lakukan adalah tindak kejahatan yang akan berujung pada proses hukum.

3. Represif

Upaya ini merupakan upaya yang dilakukan ketika upaya preventif dan preventif gagal mencegah suatu kejahatan. Oleh karena itu, upaya represif harus dilakukan, yaitu melalui tindakan yang konsisten terhadap para pelakunya.

Upaya tersebut juga meliputi penuntutan melalui penindakan langsung berdasarkan laporan tindak pidana asusila, yang meliputi penangkapan, penyidikan, penyidikan, sampai dengan dan termasuk mengambil tindakan tegas sesuai dengan tindak pidana asusila yang dilakukan apabila terbukti bahwa pelaku telah melakukan tindak pidana lain yang diatur Undang-Undang. tetapi perhatikan terlebih dahulu dan pertimbangkan manfaat yang menyertainya.

Tujuan penindakan terhadap pelaku tindak pidana asusila adalah untuk menimbulkan efek jera bagi pelakunya. Efek jera ini disebabkan oleh ancaman negara untuk memberlakukan KUHP dan Undang-Undang Nomor 11 Tahun 2008 terhadap ITE dan hukum disiplin yang berlaku yang menurut pelaku kejahatan tidak akan dilakukan lagi. Selama ini pemerintah dan lembaga penegak hukum serta instansi terkait telah banyak mengeluarkan peraturan, kebijakan, dan pedoman untuk memerangi kejahatan yang terjadi di masyarakat. Semua ini dilakukan untuk mengurangi kejahatan.

\section{KESIMPULAN}

Adapun faktor-faktor terjadinya kejahatan asusila melalui dunia maya di Makassar terdiri dari empat faktor yaitu; kesadaran hukum, struktur hukum, budaya hukum dan lingkungan. Upaya penanggulangan kejahatan asusila melalui dunia maya terdiri dari tiga upaya; (1) Pre-Entif yaitu melakukan pencegahan dini atau menanamkan nilai-nilai baik serta membangun kesadaran hokum didalam masyarakat dengan melakukan penyuluhan hokum terkait aturan tentang kejahatan asusila, (2) Preventif yaitu penegak hukum di harapkan melakukan patrol dalam rangka mencegah tindakan pelaku untuk melakukan kejahatan, (3) Refresif yaitu menjerat para pelaku kejahatan asusila di dunia maya yang seberatberatnya sehingga dapat menjadi efek jerah baik pelaku maupun masyarakat umum.

\section{DAFTAR PUSTAKA}

_.1983, Manusia dan Kejahatan, Lembaga Kriminologi, Ujung Pandang : Unhas.

_.1983. Dasar - Dasar Hukum Pidana. Sinar Baru, Bandung.

_2005. Tindak Pidana Mengenai Kesopanan, Jakarta: Raja Grafindo Persada.

_.1982, Aneka Permasalahan Dalam Ruang Lingkup Kriminologi, bandung : Alumni.

_.1991, Upaya Non Penal dalam Penanggulangan Kejahatan, PT. Citra Aditya Bakti, Semarang.

2013 Aspek Hukum Pidana Kejahatan Mayantara, Aswaja Pressindo, Yogyakarta.

A. S Alam, Pengantar Kriminologi, 2010.

Abdul Manan, Apek-aspek Pengubah Hukum, (Jakarta : Kencana, 2006)

Abdul Wahid dan M. Labib, Kejahaan Mayantara(cybercrime), (Bandung: Refika Aditama, 2005),

Abintoro Prakoso, 2013, Kriminologi dan Hukum Pidana, Laksbang Grafika, Yogyakarta.

Abussalam, 2007, Kriminologi, Restu Agung, Jakarta.

Adami Chazawi,2013, Pelajaran Hukum Pidana ,Rajawali Pers, Jakarta,

Ade Arie Sam Indradi, carding-modus operandi, Penyifikan dan Penindakan, (Jakarta: Grafika Indah,2006),

Agus Raharjo, 2002, Cyber Crime: Pemahaman dan Upaya Pencegahan Kejahatan Berteknologi, PT citra Aditya Bakti, Bandung.

Andi Hamzah, 1986, Bunga Rampai Hukum Pidana dan Acara Pidana, Ghalia Indonesia, Jakarta

Andi Hamzah, 1992, Aspek-aspek Pidana di bidang Komputer, Sinar Grafika, Jakarta

Andi Zainal Abidin Farid, 1981, Hukum Pidana I, Sinar Grafika, Jakarta.

Bambang Poernomo, 1987, Asas-Asas Hukum Pidana, Ghalia Indonesia, Jakarta.

Barda Nawai Arif,2006, Tindak Pidana Mayantara"Perkembangan Kajian Cyber Crime di Indonesia", Raja Grafindo Persada, Jakarta.

Budi Suhariyanto, Tindak Pidana Teknologi Informasi (cybercrime), (Jakarta: PT RajaGrafindo Persada, 2012),

Chazawi, Adami, 2002. Pelajaran Hukum Pidana I, Jakarta: Raja Grafindo Persada.

Departemen Pendidikan dan Kebudayaan, 1991, Kamus Bahasa Indonesia, Jakarta

Didik M Arief Mansur dan Elisataris Ghukthom,2005, Cyber Law Aspek Hukum Teknologi Informasi, (Bandung:Refika Aditama)

Fridmann Lawrence M. ,2001, American Law An Intruduction, PT Tatanusa, Jakarta.

Gerson W. Bawengan, 1977, Masalah Kejahatan dengan Sebab dan Akibatnya, Pradnya Paramita, Jakarta.

Hari Sasangka, 2003, Narkotika dan Psikotropika dalam Hukum Pidana, Mandar Maju, Bandung. 
Hari, Saherodji, 1980, Pokok-Pokok Kriminologi, Jakarta : Aksara Baru.

Hartoyo, 2007, Budaya Hukum dalam Implementasi Kebijakan Pemerintah terhadap Persyaratan Pengelolaan Apotik di Kota, Eprints.Undip.

John M. Echols dan Hassan Sadhily, 2002, Kamus Inggris - Indonesia, Gramedia Jakarta.

Josua Sitompul, 2013, Penanganan Cyber Crime di Indonesia,

Kanter dan Sianturi, 2002, Asas-asas Hukum Pidana di Indonesia dan Penerapannya. Storia Grafika, Jakarta

Kitab Undang-Undang Hukum Acara Pidana (KUHAP)

Lamintang, 1981, Kitab Pelajaran Hukum Pidana; Leekboek Van Het Nederlanches Straftrecht, Pionir Jaya, Bandung.

Marpaung, Leden, 2008. Kejahatan Terhadap Kesusilaan Dan Masalah Prevensinya, Jakarta: Sinar Grafika.

Marzuki, Peter Mahmud. 2008. Penelitian Hukum. Kencana Persada Media Group. Jakarta.

Merry Magdalena dan Maswigrantoro Rous Setyandu, 2007, cyber law tidak perlu takut, Yogyakarta.

Moeljatno, 1985, Asas-asas Hukum Pidana, Bina Aksara, Jakarta

Monks, F.J,K \& Haditono, S.R. 1999. Psikologi Perkembangan. Gadjah Mada University Press, Yogyakarta.

Muhammad Abdulkadir, 2004 , Hukum dan Penelitian Hukum, PT Citra Aditia Bakti.

Mulyana W, Kusuma, 1981, Kriminologi dan Masalah Kejahatan, Bandung : Amirco.

Pitlo dalam Edmon Makarim. 2003. Kompilasi Hukum Telematika, Jakarta.Rajagrafindo Persada.

Poernomo, Bambang. 2006. Pokok-pokok Tata Cara Peradilan Indonesia, Jogjakarta. Liberty.

R. Soesilo, 1985, Kriminologi (Pengetahuan tentang sebab-sebab Kejahatan), Politea, Bogor.

R.Tresna. 1995. Hukum Pidana. Sinar Baru, Jakarta.

Romli Atmasasmita, 2005, teori dan Kapita Selekta Kriminologi, aditma, bandung.

Ronny Rachman Nitibaskara, 2009,Perangkap Penyimpangan dan Kejahatan, YPKIK,Jakarta.

Rusli Effendy, 1983, Ruang Lingkup Kriminologi, Alumni, Bandung

Sahetapy dan Mardjono Reksodiputro, 1982, Paradoks dalam Kriminologi, Rajawali, Jakarta

Sajipto Raharjo, Hukum dan Pembaharuan Sosial, Bandung, Alumni, 1983

Santoso, Topo, dan Achjani Zulfa, Eva,. 2001, Kriminologi, Jakarta : Raja Grafindo Persada.

Sarwono, S.W. 2002. Psikologi Remaja. Edisi Enam, Raja Grafindo Persada, Jakarta.

Singgih Gunarso, 1985, Psikologi Remaja, Cet VII, Gunung Mulia, Jakarta.

Soedjono Dirdjosiswo, 1984, Ruang Lingkup Kriminologi, remaja Karya, bandung.

Soekanto, Soerjono. 1990. Sosiologi Suatu Pengantar, Rajawali Pers, Jakarta.

Soemitro Ronny Hanintijo, 1988 , Metode Penelitian Hukum Dan Jurimetri, Ghalia Indonesia
Sudarto, 1990, Hukum Pidana, Purwokerto:Fakultas Hukum Universitas jenderal Soedirman Purwokerto Tahun Akademik 1990-1991,

Sukanto Soerjono, 1984 , Pengantar Penelitian hukum, Universitas Indonesia Press, Jakarta

Suryabrata, S. 1981. Psikologi Kepribadian. Rajawali Press, Jakarta.

Syaharuddin Nawi, 2014, Penelitian Hukum Normatif Versus Penelitian Hukum Empiris, Umitoha Ukhuwah Grafika, Makassar.

Syamsuddin Pasamai, 2013, Sejarah dan Sejarah Hukum, Arus Timur, Makassar

Tim Realiti, 2008, Kamus Terbaru Bahasa Indonsia, Reality Publisher, Surabaya

Undang-Undang Nomor 11 Tahun 2008 tentang Informasi dan Transaksi Ektronik.

Utrecht, 1983, Pengantar dalam Hukum Indonesia, Icthtiar Baru, Jakarta,

Van Apeldoorn, 1985, PengantarlmuHukum,Pradya Paramita, Jakarta,

Volodymyr Golubev, Cyber crime and legal problrms of internet usage,

Widodo, 2009, Sistem Pemidanaan Dalam Cyber Crime, Laksbang Mediatama.

Widyopramono. 1994. kejahatan di Bidang Komputer. Pustaka Sinar Harapan,Jakarta.

Wiryono Prodjodikoro, 1986, Tindakan-Tindakan pidana Tertentu di Indonesia, Bandung: Erosco. 